\title{
Comparison of Hemogram Parameters in Febrile Seizures Types
}

\author{
Febril Nöbet Tiplerinde Hemogram Parametrelerinin Karşılaştırılması
}

\author{
Zühal ÖRNEK ${ }^{1}$ \\ (1) 0000-0001-9252-1652 \\ Hakan KARDEŞ ${ }^{1}$ \\ (D) 0000-0002-0553-7072 \\ İbrahim Etem PİŞKİN ${ }^{2}$ \\ (1) 0000-0002-1651-6639 \\ Mustafa CCALIK ${ }^{3}$ \\ (1) 0000-0002-6389-3355
}

${ }^{1}$ Bülent Ecevit University Faculty of Medicine Department of Pediatrics, Zonguldak, Turkey

${ }^{2}$ Bülent Ecevit University Faculty of Medicine Department of Pediatric Intensive Care, Zonguldak, Turkey

${ }^{3}$ Harran University Faculty of Medicine Department of Pediatric Neurology, Şanlıurfa, Turkey

\section{Corresponding Author Sorumlu Yazar Zühal ÖRNEK zuhalornek@gmail.com}

Received / Geliş Tarihi : 02.10.2019 Accepted / Kabul Tarihi : 22.01.2020 Available Online /

Çevrimiçi Yayın Tarihi : 25.04.2020

\begin{abstract}
Aim: Febrile seizures (FS) are among the most common neurological emergencies during childhood and clinically classified into two types, being simple febrile seizures (SFS) and complicated febrile seizures (CFS). The differentiation between FS types is important, in that they are associated with different morbidity and mortality risks and it is based on the clinical characteristics of each seizure, however there is currently no laboratory test that can guide this differentiation. In this study, the relationship between FS types and hemogram parameters was evaluated and potential use of these parameters in differential diagnosis was investigated.

Material and Methods: This retrospective study included a total of 133 patients whose first FS met the criteria of an FS, and whose hemogram results were available. The American Academy of Pediatrics criteria were used to confirm the diagnosis. The patients were divided into two groups as SFS and CFS.

Results: Hemoglobin $(\mathrm{Hb})$, hematocrit (HCT), mean platelet volume (MPV), neutrophil lymphocyte ratio (NLR) and platelet lymphocyte ratio (PLR) differed significantly between two groups $(p<0.001, p=0.002, p=0.033, p<0.001, p<0.001$, respectively), while no significant difference was identified in total blood count parameters. Moreover, MPV was significantly higher in CFS group than in SFS group.

Conclusion: This is one of the few studies investigating the potential relationship between hemogram parameters and FS types in children. We believe that, although they do not ensure a clear differentiation, Hb, MPV, NLR and PLR may be useful to clinicians in differentiating between FS types, particularly in patients with an unclear seizure history.

Keywords: Febrile seizures; simple; complicated; hemogram.
\end{abstract}

ÖZ

Amaç: Febril nöbetler (FN) çocukluk çağında en sık görülen nörolojik aciller arasındadır ve klinik olarak basit febril nöbetler (BFN) ve komplike febril nöbetler (KFN) olmak üzere iki tipte sınıflandırılır. FN tiplerinin ayrımı, farklı morbidite ve mortalite riskleriyle ilişkili olması ve her nöbetin klinik özelliklerine dayanması nedeniyle önemlidir, ancak şu anda bu farklılaşmaya yol gösterecek laboratuvar testi bulunmamaktadır. Bu çalışmada FN tipleri ve hemogram parametreleri arasındaki ilişki incelenmiş ve bu parametrelerin ayırıcı tanıda potansiyel kullanımı araştırılmışırır.

Gereç ve Yöntemler: Bu retrospektif çalışmaya, FN kriterlerine uyan, ilk defa FN geçiren ve hemogram sonuçlarına ulaşılabilen toplam 133 hasta dahil edildi. Tanıyı doğrulamak için Amerikan Pediatri Akademisi kriterleri kullanıldı. Hastalar BFN ve KFN olmak üzere iki gruba ayrild.

Bulgular: Her iki grup arasında hemoglobin $(\mathrm{Hb})$, hematokrit $(\mathrm{HCT})$, ortalama trombosit hacmi (MPV), nötrofil lenfosit oranı (NLO) ve trombosit lenfosit oranı (TLO) değerleri anlamlı şekilde farklıyken (sırasıyla $p<0,001 ; p=0,002 ; p=0,033 ; p<0,001 ; p<0,001$ ) diğer tam kan sayımı parametrelerinde ise anlamlı bir farklılık yoktu. Ayrıca, KFN grubunda MPV, BFN grubuna göre anlamlı derecede yüksekti.

Sonuç: $\mathrm{Bu}$ çalışma çocuklarda hemogram parametreleri ile FN tipleri arasındaki potansiyel ilişkiyi araştıran az sayıdaki çalışmadan biridir. Hemoglobin, MPV, NLO ve TLO'nun kesin bir ayrım sağlamasa da özellikle nöbet hikayesi net olmayan hastalarda klinisyenlere FN tiplerinin ayırt edilmesinde yardımcı olacağını düşünmekteyiz.

Anahtar kelimeler: Febril nöbetler; komplike; basit; hemogram. 


\section{INTRODUCTION}

Febrile seizures (FS) are among the most common neurological emergencies seen during childhood. The commonly accepted criteria for FS include a fever higher than $38^{\circ} \mathrm{C}$, absence of a central nervous system infection or inflammation, lack of an underlying metabolic abnormality that may cause convulsions, and absence of a previous history of afebrile seizures in children aged 6-60 months. FS is seen in $2-5 \%$ of all children, and its incidence peaks at the age of 18 months. FSs are clinically classified into two types, being simple febrile seizures (SFS) and complicated febrile seizures (CFS). SFSs were defined as primary generalized seizures that lasted for less than 15 minutes and did not recur within 24 hours. CFSs were defined as focal, prolonged ( $\geq 15$ minutes), and/or recurrent within 24 hours (1). SFS and CFS account for $80 \%$ and $20 \%$ of all febrile seizures, respectively (2).

It is important to differentiate between the different types of FSs, as they are associated with different risks of morbidity and mortality (3), and this differentiation is made based on the clinical characteristics of each seizure, as there is currently no laboratory test that can guide this differentiation. The majority of previous studies about FS in literature focus on the risks of FS, the development of epilepsy, recurrence and prophylaxis of the disease. In the present study, we investigate the relationship between FS types and hemogram parameters, and evaluate the potential use of these parameters in differential diagnosis.

\section{MATERIAL AND METHODS}

A total of 133 patients aged between 6 and 60 months who referred to the pediatric emergency care unit of the Bülent Ecevit University Medical Faculty between January 2009 and January 2017 with their first FS, and whose hemogram results were available, were included in the study. Ethics committee approval was obtained from the Bülent Ecevit University Medical Faculty Research Hospital Ethics Committee, with approval date 08.03.2017 and protocol number 2017-29-08/03. Medical data of the patients was reviewed retrospectively, and the American Academy of Pediatrics (AAP) criteria was used to confirm the diagnosis of FS. According to AAP criteria; FS is a seizure accompanied by fever $\left(\geq 38^{\circ} \mathrm{C}\right)$, without central nervous system infection, occurring in infants and children between the ages of 6 to 60 months. SFSs were defined as primary generalized seizures that lasted for less than 15 minutes and did not recur within 24 hours. CFSs were defined as focal, prolonged ( $\geq 15$ minutes), and/or recurrent within 24 hours. Patients were divided into two groups as SFS and CFS (1).

A lumbar puncture was performed in patients with signs of meningeal irritation and no fever focus. Then patients with negative growth cultures were included in the study. Patients who were suffered from afebrile seizures, with cerebral palsy and/or mental retardation, and those who had experienced a previous FS were excluded from the study.

\section{Laboratory Analysis}

The hemogram parameters, measured from peripheral blood obtained at the initial presentation, were evaluated. White blood cell count (WBC), red blood cell count (RBC), hemoglobin $(\mathrm{Hb})$, mean erythrocyte volume (MCV), hematocrit (HCT), erythrocyte distribution width (RDW), platelet count (PLT), mean platelet volume (MPV), platelet distribution width (PDW), plateletcrit (PCT), neutrophil lymphocyte ratio (NLR) and platelet lymphocyte ratio (PLR) were recorded. NLR was calculated by dividing the neutrophil count by the lymphocyte count, and PLR was calculated by dividing PLT by lymphocyte count. Patients were considered anemic if $\mathrm{Hb}$ values were $10.5 \mathrm{gr} / \mathrm{dl}$ and lower in the 6-24 months age group and $11.5 \mathrm{~g} / \mathrm{dl}$ or lower in the 25-60 months age group (4).

\section{Statistical Analysis}

Statistical analyses were performed with SPSS 19.0 software (SPSS Inc., Chicago, IL, USA) and MedCalc 19.0.6 (demo version). Distribution of data was determined by Shapiro-Wilk test. Continuous variables were expressed as mean \pm standard deviation, categorical variables as frequency and percent. Categorical variables were compared using Pearson's Chi-square test. Independent samples $\mathrm{t}$ test was used for $\mathrm{Hb}$ and $\mathrm{HCT}$ and Mann-Whitney $U$ test was used for the rest of the hemogram parameters to compare two groups in terms of continuous variables. A receiver operating characteristic (ROC) analysis was constructed to determine the best cutoff value to predict the outcome. A p value of less than 0.05 was considered statistically significant for all tests.

\section{RESULTS}

The study included 133 (57 girls, 76 boys) patients whose medical files were reviewed retrospectively. The patients were evaluated in two groups, as those with SFS $(\mathrm{n}=105$, $78.9 \%)$ and those with CFS $(n=28,21.1 \%)$. The mean age and gender distribution were not significantly different between two groups ( $\mathrm{p}=0.812, \mathrm{p}=0.830$, respectively). In terms of age distribution, $21.1 \%(\mathrm{n}=28)$ of the cases were younger than 12 months, $52.6 \%(\mathrm{n}=70)$ were aged between 13 and 24 months, $15.8 \%(\mathrm{n}=21)$ were aged between 25 and 36 months, $6.0 \%(\mathrm{n}=8)$ were aged between 37 and 48 months and $4.5 \%(n=6)$ were older than 48 months. The seizure types did not differ significantly between the age groups $(\mathrm{p}=0.254$, Table 1$)$.

While Hb ( $<0.001)$, HCT ( $=0.002)$ MPV $(\mathrm{p}=0.033)$, NLR $(p<0.001)$ and PLR $(p<0.001)$ values were statistically significantly different between the two groups, no significant difference was noted in the total blood count parameters. Of all the patients, $36.1 \%(\mathrm{n}=48)$ had anemia, and $29.5 \%(n=31)$ of those were in the SFS and $60.7 \%$ $(n=17)$ were in the CFS group. Table 2 shows the mean hemogram parameter values in each group.

Table 1. Age and gender distribution of febrile seizure types

\begin{tabular}{cccc}
\hline & SFS $(\mathbf{n = 1 0 5})$ & CFS $(\mathbf{n = 2 8})$ & $\mathbf{p}$ \\
\hline Age (month), mean \pm SD & $21.63 \pm 11.54$ & $24.28 \pm 16.13$ & 0.812 \\
Age, n (\%) & & & \\
$\leq 12$ & $21(20.0)$ & $7(25.0)$ & \\
$13-24$ & $56(53.2)$ & $14(50.0)$ & \\
$25-36$ & $19(18.1)$ & $2(7.1)$ & 0.254 \\
$37-48$ & $6(5.7)$ & $2(7.1)$ & \\
$\geq 49$ & $3(2.9)$ & $3(10.7)$ & \\
Gender, $\mathbf{n}(\%)$ & & & \\
Girl & $44(41.9)$ & $13(46.4)$ & 0.830 \\
Boy & $61(58.1)$ & $15(53.6)$ & \\
\hline
\end{tabular}

SFS: Simple febrile seizure, CFS: Complicated febrile seizure, SD: Standard deviation 
When the strength of markers in predicting CFS was evaluated, the area under curve (AUC) values were found to be low and similar. AUC values of NLR-PLR and Hb-MPV were not significantly different $(p=0.970$ and $p=0.314$, respectively). Table 3 shows the cut-off, AUC, sensitivity, specificity, $95 \%$ confidence interval $(\mathrm{CI})$ and $\mathrm{p}$ values of the $\mathrm{Hb}, \mathrm{HCT}, \mathrm{MPV}, \mathrm{NLR}$ and PLR parameters for predicting CFS, while the ROC curves are presented in Figures 1 and 2.

Table 2. Hemogram parameters according to groups

\begin{tabular}{|c|c|c|c|c|c|}
\hline \multirow{2}{*}{ Hemogram Parameters } & \multicolumn{2}{|c|}{ SFS $(n=105)$} & \multicolumn{2}{|c|}{ CFS $(n=28)$} & \multirow{2}{*}{$\mathbf{p}$} \\
\hline & Mean \pm SD & Median (Min-Max) & Mean \pm SD & Median (Min-Max) & \\
\hline WBC $\left(\times 10^{3} / \mathrm{mm}^{3}\right)$ & $13.71 \pm 5.90$ & $13.30(4.80-35.00)$ & $14.45 \pm 8.59$ & $12.45(3.70-37.10)$ & 0.858 \\
\hline $\mathrm{RBC}\left(10^{6} / \mathrm{mL}\right)$ & $4.45 \pm 0.38$ & $4.46(3.38-5.40)$ & $4.25 \pm 0.54$ & $4.36(2.30-5.18)$ & 0.074 \\
\hline $\mathrm{Hb}(\mathrm{g} / \mathrm{dL})$ & $11.40 \pm 1.03$ & $11.40(8.70-13.70)$ & $10.50 \pm 1.05$ & $10.45(8.40-12.20)$ & $<0.001$ \\
\hline $\operatorname{HCT}(\%)$ & $33.46 \pm 2.81$ & $33.70(26.70-39.50)$ & $31.45 \pm 3.30$ & $33.70(23.70-37.00)$ & 0.002 \\
\hline $\operatorname{MCV}(\mathrm{fl})$ & $75.31 \pm 5.51$ & $76.00(56.60-83.90)$ & $74.35 \pm 8.25$ & $74.30(56.70-102.70)$ & 0.128 \\
\hline RDW (\%) & $14.94 \pm 1.96$ & $14.60(12.10-25.00)$ & $15.56 \pm 2.19$ & $14.95(12.60-20.80)$ & 0.132 \\
\hline $\operatorname{PLT}\left(10^{3} / \mu \mathrm{L}\right)$ & $310.81 \pm 113.48$ & $300.00(113.00-873.00)$ & $294.14 \pm 104.28$ & $278.00(144.00-585.00)$ & 0.347 \\
\hline PCT $(\%)$ & $0.223 \pm 0.071$ & $0.214(0.090-0.530)$ & $0.221 \pm 0.070$ & $0.205(0.125-0.422)$ & 0.747 \\
\hline PDW (\%) & $16.51 \pm 0.62$ & $16.50(15.20-18.40)$ & $16.82 \pm 0.72$ & $16.70(15.90-18.70)$ & 0.072 \\
\hline MPV (fl) & $7.32 \pm 0.88$ & $7.20(5.80-9.70)$ & $7.70 \pm 0.94$ & $7.65(5.70-9.10)$ & $\mathbf{0 . 0 3 3}$ \\
\hline $\operatorname{NLR}(\%)$ & $3.80 \pm 3.49$ & $2.81(0.26-21.00)$ & $8.90 \pm 8.12$ & $5.75(1.52-35.43)$ & $<0.001$ \\
\hline PLR (\%) & $125.20 \pm 96.94$ & $102.66(22.11-683.30)$ & $200.72 \pm 118.41$ & $162.50(52.88-456.00)$ & $<0.001$ \\
\hline
\end{tabular}

SFS: Simple febrile seizure, CFS: Complicated febrile seizure, SD: Standard deviation, Min: Minimum, Max: Maximum, WBC: White blood cell count, RBC: Red blood cell count, Hb: Hemoglobin, HCT: Hematocrit, MCV: Mean erythrocyte volume, RDW: Erythrocyte distribution width, PLT: Platelet count, PCT: Plateletcrit, PDW: Platelet distribution width, MPV: Mean platelet volume, NLR: Neutrophil lymphocyte ratio, PLR: Platelet lymphocyte ratio

Table 3. The results of ROC analysis

\begin{tabular}{lcccccc}
\hline Hemogram parameters & Cut-off value & Area Under Curve & Sensitivity & Specificity & \%95 Confidence Interval & p \\
\hline $\mathrm{Hb}$ & $\leq 10.5$ & 0.709 & 57.14 & 80.00 & $0.624-0.784$ & $<\mathbf{0 . 0 0 1}$ \\
$\mathrm{HCT}$ & $\leq 31.5$ & 0.669 & 50.00 & 76.19 & $0.582-0.748$ & $\mathbf{0 . 0 0 2}$ \\
$\mathrm{MPV}$ & $>6.9$ & 0.632 & 85.71 & 39.05 & $0.544-0.714$ & $\mathbf{0 . 0 3 4}$ \\
$\mathrm{NLR}$ & $>5.6$ & 0.724 & 57.14 & 83.02 & $0.640-0.798$ & $<\mathbf{0 . 0 0 1}$ \\
$\mathrm{PLR}$ & $>141.9$ & 0.727 & 71.43 & 76.19 & $0.642-0.800$ & $<\mathbf{0 . 0 0 1}$ \\
\hline
\end{tabular}

Hb: Hemoglobin, HCT: Hematocrit, MPV: Mean platelet volume, NLR: Neutrophil lymphocyte ratio, PLR: Platelet lymphocyte ratio

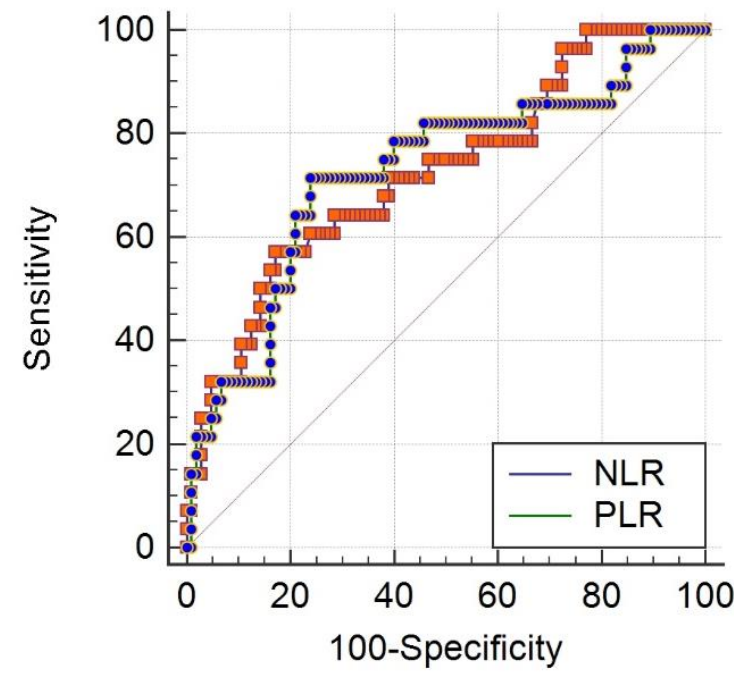

Figure 1. Comparison of ROC curves for neutrophil lymphocyte ratio (NLR) and platelet lymphocyte ratio (PLR)

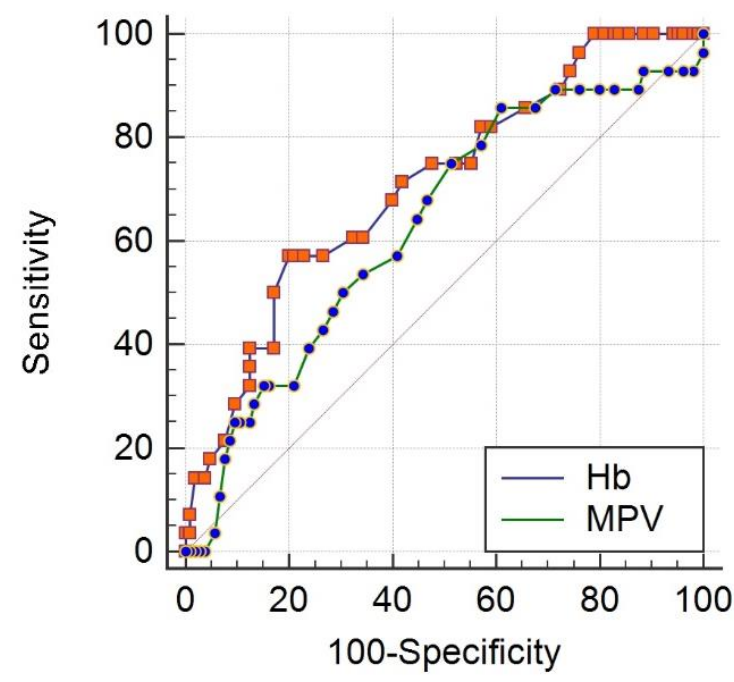

Figure 2. Comparison of ROC curves for hemoglobin $(\mathrm{Hb})$ and mean platelet volume (MPV) 


\section{DISCUSSION}

Based on a clinical diagnosis, FSs are classified into two types as SFS and CFS (1). Both conditions are generally not expected to have long-term consequences on motor or cognitive development, although CFS has been associated with a slightly higher rate of epilepsy (5). The clinical differentiation of FS types may be further complicated by ineffective anamnesis provided by the families in a state of panic, as well as the change in or complete resolution of physical examination findings at admission due to anticonvulsive treatments administered to the patients during their transfer to hospital. Both seizure types require different approaches and management strategies, and it is therefore important to define the type of each seizure $(1,6)$. The majority of studies about FS in the literature focus on the risks associated with FS, the development of epilepsy, FS recurrence, treatment and prophylaxis. Aside from clinical identification, some recent studies have evaluated the role of laboratory parameters in the differentiation of FS types. It has been suggested that there is currently no laboratory test with a specifically proven value in the management of a child having FS, and these tests only become helpful when accompanied by symptoms and findings of an important disease. While no investigation has been recommended for SFS, it is recommended that clinicians should carry out further investigations in patients with CFS due to the potential long-term risks (7). In the present study, we made a retrospective evaluation of the medical files of patients to investigate the potential use of hemogram parameters in the differentiation of FS types. The mean age of the overall study population was $22.19 \pm 12.62$ months and FSs were most frequently experienced by patients younger than 24 months of age. These results are consistent with previously reported findings $(8,9)$. The incidence of FS reaching a peak and overlapping that of iron deficiency anemia (IDA) is most commonly seen between the ages of 12 and 24 months (10). Elemental changes such as iron deficiency are considered to play a role in the development of FS (11), leading to the relationship between anemia and FS being investigated in several studies (12-14). Pisacane et al. (15) were the first to investigate this relationship in children of similar age groups, and suggested that iron deficiencies facilitated the development of seizures. In studies carried out in Iran and Pakistan, the odds of IDA occurring in children with a history of FS were found to be 1.27 and 1.93-fold higher, respectively, than the control group $(12,16)$. The SFS and seizure-free pyretic disease groups were compared in another study, and the rate of IDA was found to be significantly different in favor of SFS (17). In contrast, there have been other studies in which no significant relationship was identified between anemia and FS $(13,18)$. In the limited number of studies in our country investigating the relationship between IDA and FS $(14,19)$, IDA is reported in $35-48 \%$ of children with FS. In a study by Ozaydın et al. (20), IDA was found to be more common among patients with CFS when compared to SFS, and CFS was also associated with lower $\mathrm{Hb}, \mathrm{HCT}$ and MCV values. Due to its retrospective design, it was not possible to evaluate the etiology of anemia in the present study. Of all the patients, $36.1 \%$ had anemia, and $64.6 \%$ of those were in the SFS group, and $35.4 \%$ were in the CFS group. The mean $\mathrm{Hb}$ and $\mathrm{HCT}$ values were found to be low in the CFS group, and this low level was considered significant. A ROC analysis identified the cut-off $\mathrm{Hb}$ and HCT levels for CFS as $10.5 \mathrm{~g} / \mathrm{dl}$ and $31.5 \%$, respectively. Previous studies have suggested that anemia may increase the rate of FS development, or may even trigger FS. In the present study, although the number of patients with anemia was lower in the CFS group than in the SFS group, the mean $\mathrm{Hb}$ value was still lower in the CFS group. It is not possible here to speculate on the relationship between anemia and FS development due to the retrospective design of the present study and absence of a control group, although the $\mathrm{Hb}$ value may be considered a useful marker in the differentiation of seizure types.

RDW is a routinely used test to define the etiology of anemia, and is an index that automatically measures the heterogeneity of erythrocytes. Moreover, RDW has been shown to be positively correlated with inflammatory markers in the presence of certain diseases (such as cardiovascular and autoimmune diseases and cancer) and can therefore be considered as a potential inflammatory marker (21). In a study by Goksugur et al. (22), RDW was shown to be a simple, effective and practical marker for the differentiation of FS types, while another study has reported that RDW was not significantly helpful in the differentiation of FS types (23). In the present study, the mean RDW value was elevated in the CFS group, although the difference between two groups was not statistically significant. As RDW may be influenced by several parameters, including the method of measurement, additional prospective studies including larger patient groups are required to better understand the role of RDW in differentiating between seizure types.

There is evidence that inflammatory cells and proinflammatory cytokines play significant roles in the etiopathogenesis of febrile seizures, as inflammation enhances neuronal excitability in the brain and decreases seizure threshold. Platelets have been shown to play critical roles not only in hemostasis, but also in the immune system and in inflammation, and there have been studies investigating the relationship between platelet indexes and FS (24). Platelet indexes, including PLT, MPV, PDW and PCT, are all markers of platelet activity, and the MPV reflects the size of platelets and the rate of platelet production in bone marrow. This can be considered as an easily accessible marker of platelet activation that does not result in any additional cost, and the method has been investigated related to several diseases as a marker of platelet activation and the severity of inflammation (2224). A study investigating the relationship between febrile seizure types and MPV considered epilepsy as an inflammatory disease of the brain, and demonstrated significantly lower MPV values in the presence of CFS. A ROC analysis was indicated that the optimum cut-off MPV level for CFS as $8.25 \mathrm{fL}$ (20). Contradicting of the findings of this study, a study by Ozkale et al. (25) investigating the relationship between platelet indexes and FS found that the increased platelet cycle in the CFS group, decreased PLT and the markedly increased MPV value, was considered to play a significant role in the prediction of FS severity in children. In two further studies it was reported that decreases or increases of MPV were not significantly different between the two types of FS $(22,26)$, but that 
MPV was significantly higher in the CFS group than in the SFS group. The corresponding cut-off value for MPV was $6.9 \mathrm{fL}$ and this level had $85.71 \%$ sensitivity and $39.05 \%$ specificity for use in the differential diagnosis of CFS and SFS (AUC=0.632). We believe that further studies should be made involving larger patient populations, as previous studies have demonstrated different MPV cut-off values. PDW is a marker of platelet volume variation, and increases in the presence of platelet anisocytosis. PCT, on the other hand, is the ratio of total platelet volume to total blood volume. While an MPV decrease or increase has been associated with febrile seizures in some studies, only a few studies have investigated PDW in FS. In the study by Ozkale et al. (25), MPV and PDW values measured one hour after a seizure were found to be higher in the CFS group than in the SFS group, while no difference between the two groups was identified after one month. The increased MPV and PDW values were thought to reflect the increased severity of inflammation in the CFS group. In the present study, PCT and PDW were not significantly different between the two groups.

The ratio of neutrophils and platelets to lymphocytes, which may be used as stand-alone inflammatory markers, can also be helpful as markers of early inflammation (27). The physiological response of circulating leukocytes under various stress conditions is characterized by an increase in the neutrophil count and a decrease in the lymphocyte count. Zahorec R. (28) showed that neutrophil and lymphocyte counts (absolute and/or relative percentages) and their ratios, as markers of systemic inflammation, are easily-measured parameters that may reflect disease severity. In addition, there have been several studies in literature investigating the relationship between the NLR value and different clinical conditions, such as pneumonia, acute abdomen, and chronic liver failure $(29,30)$. Recent studies have also evaluated the role of NLR in differentiating febrile seizure types, and it has been indicated that NLR has a potential value in FS management $(22,24)$. In the present study, NLR was significantly different between the two groups, and a ROC analysis showed that an NLR cut-off value of $5.58 \mathrm{had}$ a sensitivity and specificity of $57.14 \%$ and $83.02 \%$, respectively. Cut-off values for NLR were reported as 2.134 in the study by Yigit et al. (24) involving 142 patients, while these values were reported as 1.98 in the study by Goksugur et al. (22), including 112 patients. Despite the number of patients in the present study being similar to previous studies, we identified a higher cut-off value in this study. We believe that NLR may serve as a useful guide for clinicians as an objective, cheap and easily calculated parameter that is used routinely in clinical practice and it does not incur any additional costs.

Like NLR, the PLR is also an effective and simple thrombo-inflammatory marker that may reflect inflammation. It has been suggested to use as a predictive and prognostic parameter in several conditions, including cardiovascular diseases, pneumonia, Hepatitis B and C, vestibular neuritis, thyroid disorders and malignancies, and has also been associated with gestational diabetes mellitus, acute appendicitis, preeclampsia, recurrent pregnancy loss and preterm delivery in pregnant women (30-32). PLR was significantly different between the two groups in the present study, and a ROC analysis showed a cut-off PLR value as 141.9. The PLR is also an objective and cheap parameter that can be easily calculated and used routinely in clinical practice.

When the AUC for NLR-PLR and Hb-MPV were compared in the present study, no significant differences were noted. Accordingly, we believe that all of these parameters are suitable for the differentiation of the two seizure types.

In conclusion, this is one of the few studies investigating the relationship between hemogram parameters and FS types in children. Although this study has a relatively small sample size, we believe that our findings may help clinicians in using $\mathrm{Hb}$, MPV, NLR and PLR parameters to differentiate between FS types, particularly in patients with an unclear seizure history. Moreover, rather than using platelet, WBC or lymphocyte counts alone, a simultaneous evaluation of PLR and NLR values would appear to be more appropriate for the assessment of inflammation. As this study was performed retrospectively on a relatively small patient group, and demonstrated conflicting results with previous studies, we stress that larger prospective studies are required on this matter.

Conflict of Interest: Authors declared no conflict of interest.

\section{REFERENCES}

1. Subcommittee on Febrile Seizures; American Academy of Pediatrics. Neurodiagnostic evaluation of the child with a simple febrile seizure. Pediatrics. 2011;127(2):389-94.

2. Verity CM, Golding J. Risk of epilepsy after febrile convulsions: a national cohort study. BMJ. 1991;303(6814):1373-6.

3. Dubé CM, Brewster AL, Baram TZ. Febrile seizures: Mechanisms and relationship to epilepsy. Brain Dev. 2009;31(5):366-71.

4. Brugnara C, Oski FA, Nathan DG. Diagnostic approach to the anemic patients. In: Orkin SH, Nathan DG, Ginsburg D, Look AT, Fisher DE, Lux SE, editors. Nathan and Oski's hematology of infancy and childhood. 7th ed. Philadelphia: Saunders; 2008. p.463-66.

5. Choy M, Dubé CM, Ehrengruber M, Baram TZ. Inflammatory processes, febrile seizures, and subsequent epileptogenesis. Epilepsy Curr. 2014;14(Suppl 1):15-22.

6. Mastrangelo M, Midulla F, Moretti C. Actual insights into the clinical management of febrile seizures. Eur $\mathbf{J}$ Pediatr. 2014;173(8):977-82.

7. Sales JW, Bulloch B, Hostetler MA. Practice variability in the management of complex febrile seizures by pediatric emergency physicians and fellows. CJEM. 2011;13(3):145-9.

8. Okumura A, Uemura N, Suzuki M, Itomi K, Watanabe $\mathrm{K}$. Unconsciousness and delirious behavior in children with febrile seizures. Pediatr Neurol. 2004;30(5):316-9.

9. Waruiru C, Appleton R. Febrile seizures: an update. Arch Dis Child. 2004;89(8):751-6.

10. Offringa M, Bossuyt PM, Lubsen J, Ellenberg JH, Nelson KB, Knudsen FU, et al. Risk factors for seizure recurrence in children with febrile seizures: a pooled analysis of individual patient data from five studies. $\mathbf{J}$ Pediatr. 1994;124(4):574-84. 
11. Akbayram S, Cemek M, Büyükben A, Aymelek F, Karaman S, Yilmaz F, et al. Major and minor bioelement status in children with febrile seizure. Bratisl Lek Listy. 2012;113(7):421-3.

12. Nasehi MM, Abbaskhanian A, Omran MRS. Association between iron deficiency anemia and febrile seizure: A systematic review and meta-analysis. J Pediatr Rev. 2013;1(2):13-8.

13. Bidabadi E, Mashouf M. Association between iron deficiency anemia and first febrile convulsion: A casecontrol study. Seizure. 2009;18(5):347-51.

14. Ünver O, Sezer RG, Kibar AE, Ünver A, İpek İÖ, Bozaykut A. The association between febrile seizures and iron deficiency anemia in childhood. J Clin Anal Med. 2015;6(1):57-60.

15. Pisacane A, Sansone R, Impagliazzo N, Coppola A, Rolando P, D’Apuzzo A, et al. Iron deficiency anemia and febrile convulsions: case-control study in children under 2 years. BMJ. 1996;313(7053):343.

16. Sherjil A, us Saeed Z, Shehzad S, Amjad R. Iron deficiency anaemia--a risk factor for febrile seizures in children. J Ayub Med Coll Abbottabad. 2010;22(3):71-3.

17. Srinivasa S, Reddy SR. Iron defeiciency anemia in children with simple febrile seizures-A cohort study. Curr Pediatr Res. 2014;18(2):95-8.

18. Heydarian F, Vatankhah $\mathrm{H}$. The role of anemia in first simple febrile seizure in children aged 6 months to 5 years old. Neurosciences (Riyadh). 2012;17(3):226-9.

19. Çelik T. Presentation of patients admitted with febrile seizures. Ege Journal of Medicine. 2011;50(3):175-7.

20. Özaydin E, Arhan E, Çetinkaya B, Özdel S, Değerliyurt A, Güven A, et al. Differences in iron deficiency anemia and mean platelet volume between children with simple and complex febrile seizures. Seizure. 2012;21(3):211-4.

21. Lippi G, Targher G, Montagnana M, Salvagno GL, Zoppini G, Guidi GC. Relation between red blood cell distribution width and inflammatory biomarkers in a large cohort of unselected outpatients. Arch Pathol Lab Med. 2009;133(4):628-32.

22. Göksugur SB, Kabakuş N, Bekdaş M, Demircioğlu F. Neutrophil-to-lymphocyte ratio and red blood cell distribution width is a practical predictor for differentiation of febrile seizure types. Eur Rev Med Pharmacol Sci. 2014;18(22):3380-5.
23. Yıldız Y, Cakmak S, Calapoğlu T, Hocaoglu ZI, Karadeniz EG, Ozkasap S. Mean platelet volume can be used as a hospitalization criteria in pediatric patients diagnosed with acute bronchiolitis. Acta Medica Mediterranea, 2018;34(6):1997-2000.

24. Yigit Y, Yılmaz S, Akdoğan A, Halhalli HC, Özbek AE, Gencer EG. The role of neutrophil-lymphocyte ratio and red blood cell distribution width in the classification of febrile seizures. Eur Rev Med Pharmacol Sci. 2017;21(3):554-9.

25. Özkale M, Erol İ, Özkale Y, Sarıtürk Ç. Association between platelet indices and febrile seizures in children. Cukurova Med J. 2016;41(4):695-701.

26. Nikkhah A, Salehiomran MR, Asefi SS. Differences in mean platelet volume and platelet count between children with simple and complex febrile seizures. Iran J Child Neurol. 2017;11(2):44-7.

27. İlhan M, İlhan G, Gök AF, Bademler S, Verit Atmaca F, Ertekin C. Evaluation of neutrophil-lymphocyte ratio, platelet-lymphocyte ratio and red blood cell distribution width-platelet ratio as early predictor of acute pancreatitis in pregnancy. J Matern Fetal Neonatal Med. 2016;29(9):1476-80.

28. Zahorec R. Ratio of neutrophil to lymphocyte counts-rapid and simple parameter of systemic inflammation and stress in critically ill. Bratisl Lek Listy. 2001;102(1):5-14.

29. de Jager CP, Wever PC, Gemen EF, Kusters R, van Gageldonk-Lafeber $\mathrm{AB}$, van der Poll $\mathrm{T}$, et al. The neutrophil-lymphocyte count ratio in patients with community-acquired pneumonia. PLoS One. 2012;7(10):e46561.

30. Balta S, Demirkol S, Arslan Z, Demir M, Öztürk C. The neutrophil lymphocyte ratio in patients with ST segment elevation myocardial infarction. Eur Rev Med Pharmacol Sci. 2014;18(1):141.

31. Ulusoy B, Bozdemir K, Akyol M, Mişe HI, Kutluhan A, Korkmaz MH. Investigation of neutrophil-tolymphocyte ratio, platelet-to-lymphocyte ratio and mean platelet volume in patients with tinnitus. J Laryngol Otol. 2018;132(2):129-32.

32. Şahbaz A, Çiçekler H, Aynığlu Ö, Işık H, Özmen Ü. Comparison of the predictive value of plateletcrit with various other blood parameters in gestational diabetes development. J Obstet Gynaecol. 2016;36(5):589-93. 